\title{
STUDENTS' DESTRUCTIVE BEHAVIOR TOWARDS THE TEACHER IN THE TEACHING AND LEARNING PROCESS
}

\author{
Achmad Muhlis \\ State Islamic Institute of Madura \\ Email: ach_muhlis@yahoo.co.id \\ Moh. Wardi \\ Institut Dirosat Islamiyah Al-Amien Prenduan Sumenep \\ Email: mohwardi84@gmail.com \\ Muhammad Holis \\ MTsN 3 Pamekasan \\ Email: muhammadholis@gmail.com \\ Saliha Sebgag \\ University Mohamed Khider of Biskra, Algeria \\ Email: saliha.sebgag@univ-biskra.dz
}

\begin{abstract}
This study analyzes the model, factors, and alternative solutions to students' destructive behavior towards teachers in teaching-learning. It took place at Madrasah Tsanawiyah Negeri in Madura as immoral acts that violate the norms and values of social life by students to their teachers. It was qualitative research with a descriptive approach. The subjects of this study were representatives of MTsN teachers in Madura, namely MTsN 1 Sumenep, Pamekasan, MTsN 3 Pamekasan, MTsN 1 Sampang, and MTsN 1 Bangkalan. The research data was taken by the method of observation, documentation, and interviews. The results showed that destructive behavior models in destructive verbal behavior, destructive behavior in the form of physical and mental destructive behavior. Furthermore, the causes of students' destructive behavior towards teachers in learning at Madrasah Tsanawiyah Negeri in Madura were internal and external factors, including the social status of students being higher than their teachers. Students thought they have more intelligence and knowledge than their teachers. Therefore, the teachers did the home visits, parenting, and parental involvement, and educational sanctions to overcome it.
\end{abstract}


Abstrak: Penelitian ini bertujuan untuk menganalisis tentang model, faktor penyebab, serta solusi alternatif perilaku destruktif murid terhadap guru dalam pembelajaran pada Madrasah Tsanawiyah Negeri di Madura, sebagai tindakan amoral yang melanggar norma dan tatanan nilai kehidupan sosial masyarakat yang dilakukan oleh murid kepada gurunya. Jenis penelitian ini adalah penelitian kualitatif dengan pendekatan deskriptif, Subyek penelitian ini adalah keterwakilan dari Guru MTsN yang ada di Madura yaitu MTsN 1 Sumenep, Pamekasan, MTsN 3 Pamekasan, MTsN 1 Sampang, and MTsN 1 Bangkalan. Data penelitian diambil dengan metode observasi, dokumentasi dan wawancara. Hasil penelitian menunjukkan bahwa: pertama, model perilaku destruktif berupa prilaku destruktif verbal, perilaku destruktif fisik, dan perilaku destruktif mental. Kedua, Faktor penyebab perilaku destruktif murid terhadap guru dalam pembelajaran pada Madrasah Tsanawiyah Negeri di Madura karena faktor internal dan eksternal, diantaranya status sosial murid lebih tinggi dari gurunya, Murid merasa memiliki kecerdasan dan pengetahuan yang lebih dari gurunya. Ketiga, Cara mengatasi perilaku destruktif murid terhadap guru Pembinaan, Keteladanan dan Keterlibatan Orang tua "Home Visit", dan pemberian sanksi edukasi pada siswa.

Keywords: Destructive behavior; teaching; learning

\section{INTRODUCTION}

Destructive behavior is an immoral behavior that violates the norms caused by the emotional factors of the students themselves, such as the feeling of unconfident or hatred to be restraint. It makes this destructive behavior as the trigger or the early symptoms to take revenge to show their identity and existence. The destructive behavior is identical with rough, rejecting, resisting the order, even denying what is not suitable with their wish. ${ }^{1}$

Nowadays, the destructive behavior happened in SMAN 1 Torjun Sampang Madura; in the late 1st February 2018, a student's persecution was persecuted to his teacher, which caused the teacher's death. This behavior had been done at the school when the teaching and learning were in progress. The teacher reminded the students to do the task given, but he still ignored the teacher. The teacher reminded them again and again. Finally, it made the students angry and did the destructive action to the teacher to show his existence in the classroom. ${ }^{2}$

The second interesting case happened on May 3rd, 2018. They were torturing done by the student to his teacher, who also caused the teacher's death, occurred in one of the pesantren in Pamekasan. It happened because the student

1 Max Weber, Etika Protestan dan Spirit Kapitalisme, ed. TW Utomo and Yusup Priya Sudiarja (Yogyakarta: Pustaka Pelajar, 2006).

2 Arham Junaidi Firman and Nur Hidayat, "Strengthening Character Education Based On Golden Habits At SMP Muhammadiyah 1 Depok Yogyakarta," Cendekia 18, no. 2 (2020): 189-210. 
felt offended by the teachers' warning on him when he broke the pesantren's rule. The third destructive behavior occurred to show the student's existence in the teaching-learning process. It has happened in SMKN Pakong. The student at that time brought his smartphone to the classroom, the teacher recognized it. Then, the teacher took and brought the smartphone to the teacher's room. Suddenly, the student went home directly without permission from the teacher and told his parent about it. The parents directly went to school to take the smartphone. They did it roughly while having their sickle on hand. Third, the case of the teacher's viral video being bullied by the students in Kendal on Saturday, November 10, 2018, made the Indonesian Child Protection Commission (KPAI) intervene in coordination with the head of the education office Province of Central Java. Fourth, the incident that occurred at SMA AlAzhar Kelapa Gading, North Jakarta. A viral video shows a teacher teaching a class. Then, there was the sound of students saying inappropriate and harsh words. Finally, the student was expelled from the school. ${ }^{3}$

As we know, the student's immoral behavior is an inappropriate behavior of a student to the teacher. Moreover, it happened inside the classroom when the teaching-learning process is in progress. Here, Elida Prayitno, the student on the case, should have good morals and ethics as the developmental requirement to be mature. A successful adult must have a good attitude in line with the good norms; it also needs the parents' and the teachers' guide as the example. ${ }^{4}$

It is already proper for the teacher to warn the students in the teaching and learning process if they did not obey the classroom rules. It is the way to show the norms they have already had and agreed. The values from the environment will influence their behavior to other people in society, especially to teachers in the classroom. Mohammad Ali and Mohammad Asrori stated that values, ethics, and good morals are the references for adults to reach a mature personality in their daily life interaction. ${ }^{5}$

The fact is that there are destructive behaviors that students usually do to their teachers in reality. Based on observations, this happened in all madrasah Madura (MTsN 1 Sumenep, Pamekasan, MTsN 3 Pamekasan, MTsN 1 Sampang, and MTsN 1 Bangkalan). Deviations in this school can be categorized into three levels. The mild destructive behavior includes: sleeping in class, not participating in discussions, not doing assignments, not taking notes, not doing homework.

3 Abdulloh Hadziq, "Pendidikan Antikekerasan Berwawasan Lingkungan," At-Tarbawi 3, no. 1 (2018): 55-71.

4 Abd Aziz, "Zawawi-Kasus-Budi-Tragedi-Kemanusiaan-Paling-Tragis-Video," Antara Jatim, April 26, 2018.

${ }_{5}$ Ali and Asrori, Psikologi Remaja Perkembangan Peserta Didik, Jakarta: Bumi Aksara, 2010. 
Destructive behaviors that fall into the moderate category include arguing with the teacher, speaking aloud during the teaching process, disobeying the teacher. Finally, destructive behaviors that fall into the heavy category include: bullying teachers, hitting teachers, injuring their bodies, to the loss of life/death of teachers.

One of the reasons this destructive behavior happens is the adult cultural and interaction pattern shift that influences Madura's social condition. Madurese honors the morality, politeness, ethics, and morals of both teachers and parents. Even Madurese have their philosophy Bhuppa-Bhabbu', Ghuru Rato (Ayah, Ibu, Guru, Raja) in respecting others known as Madurese jargon.

Here, Weber classified the social behavior dealing with the teaching and learning process into four categories that can influence the social structure system in society. The first is instrumental rationality. It is a social behavior did by an individual that is based on their conscious consideration and choice. It also deals with the purpose of the behavior and the existence of the tool to reach it. ${ }^{6}$

The second is value-based rationality. It shows that the existing tools only become conscious consideration and calculation. But, at the same time, the relationship between its purposes and individual values is absolute. The third is traditional behavior. This type shows that individual behavior comes from the habit/ practices of the ancestors without any careful reflection and planning. Finally, affective behavior is dominated by unconscious planning and superficial review of feelings or emotions.

It supports Weber's theory, in line with what has been developed by George Homan about exchange theory. It can be categorized into three propositions. First, if someone's behavior is based on specific stimuli to get the reward, it most likely that the behavior has a connection to the same motivations and situation will be done and reoccured. Second, correlating to destructive behavior, when we let it happen, it will happen repeatedly, and it will develop to other phenomena at school. So it needs to be anticipated by the government, public figures, parents, and teachers to make the students obey the rule and guide students to a meaningful and educated activity. ${ }^{?}$

The second proposition of George Homan is that the more people get the reward for what they have done, the less the value they would get for the following deed. Therefore, if this destructive behavior is called breaking social ethics and religious disorder, all parties should give the same moral punishment.

${ }^{6}$ Max Weber, Etika Protestan Dan Spirit Kapitalisme, ed. TW Utomo and Yusup Priya Sudiarja (Yogyakarta: Pustaka Pelajar, 2006).

7 Weber, Etika Protestan Dan Spirit Kapitalisme. 
The social sentence is to the doer of violent behavior at school, moreover when the deed happened when teaching and learning are running. ${ }^{8}$

The net is the third proposition of George Horman. It is said that the more someone feels aggrieved in his relationship with others, the more significant opportunity he will get to increase his emotions. In the interaction between teacher and student in the classroom, it is not a process where an automatic stimulus is given and directly gets the response. Instead, it is a thinking process with specific competence on the side of the teacher and students. ${ }^{9}$

The most interesting thing about this research is that students' destructive behavior towards their teachers is very diverse and complex. Deviations in this school can be categorized into three levels. Mild destructive behavior includes: sleeping in class, not participating in discussions, not doing assignments, not taking notes, not doing homework. It is included in the moderate category, arguing with the teacher, talking loudly during the teaching process, and disobeying the teacher. Destructive behavior that is included in the weight category, among others: bullying the teacher, hitting the teacher, injuring his body, and death of the teacher. This research focuses on the form of students' destructive behavior. These factors influence students' violent behavior and alternative solutions in overcoming students' violent behavior in the learning process at Madrasah Tsanawiyah Madura.

\section{RESEARCH METHOD}

The method used in this research was qualitative research with a descriptive approach. ${ }^{10}$ Because the data is collected qualitatively, which meant the data gained was not in the form of interval, ordinal or discrete number, and it also describes the fact happens in the society. The kind of research used is explorative research which analyzes the data descriptively with the type of case study.

The subjects of this study were the headmaster, teachers, students, and people directly connected with the students' destructive behavior to the teacher in the teaching-learning process. At the same time, the data collected were the forms and the solutions of the students' destructive behavior to the teacher in the teaching-learning process of the representation of MTsN teachers in Madura,

8 Achmad Muhlis, "Urgency of Arabic Language to the Religious Style of Madurese Society," in 1st International Conference on Islamic Studies Islam A Friendly Cultural Religion (Pamekasan, 2017).

9 Achmad Muhlis, "Urgency of Arabic Language to the Religious Style of Madurese Society," in 1st International Conference on Islamic Studies Islam A Friendly Cultural Religion (Pamekasan, 2017).

${ }^{10}$ Achmad Muhlis, "Komunikasi Verbal Dalam Pengembangan Pembelajaran Bahasa Arab Berbasis Media Bithaqah Al-Jaibiyah,” Jurnal Okara Bahasa Dan Sastra 2, no. November (2016). 
namely MTsN 1 Sumenep, Pamekasan, MTsN 3 Pamekasan, MTsN 1 Sampang, and MTsN 1 Bangkalan.

Data analysis on qualitative analysis data cannot be linearly done, but it must use interactive analysis. ${ }^{11}$ In this research, the interactive analysis model used was a cyclical interactive analysis model due to the research focus. Therefore, it was required to have functioned before another unit is built. Thus, structural prerequisite means that a structure needs to be there before a unit is produced. ${ }^{12}$

\section{THEORETICAL FRAMEWORK}

\section{Definition of Destructive}

According to Rogers in T Pratisto, destructive behavior or attitude can interfere with the learning process. For example, they are often rude, irresponsible, and repeatedly violate school rules. These various behaviors often make the teacher angry, annoyed, and unable to deliver the lesson well. ${ }^{13}$

Various children's behaviors that can be grouped into destructive behavior include: Continuously calling the teacher and talking out of turn, talking alone when the teacher explains the subject matter, Motor anxiety (hyperactivity, wandering from the seat and irritating others, constantly swinging on the chair), an unnaturally loud voice, too often off-duty behavior, not paying attention, unable to concentrate correctly. The behavior, as mentioned earlier, is frequently encountered in classrooms. If it cannot be overcome, the learning activity process cannot occur appropriately so that learning objectives may not be maximally achieved. ${ }^{14}$

Destructive behavior violates norms caused by various emotional factors that bind and pent up in students. Thus, violent behavior can be interpreted as a symptom of a desire for revenge or showing and proving oneself and existence in learning. ${ }^{15}$

\section{Factors That Cause Destructive Behavior}

Since childhood, the development experienced also provides color in shaping a person's personality, including children's delinquency. From the aspect of

${ }^{11}$ Basrowi and Sukidin, Metode Penelitian Kualitatif Perspektif Mikro (Surabaya: Insan Cendekia, 2002).

${ }^{12}$ Seya Yuwana Sudikan, Metode Penelitian Kebudayaan (Surabaya: Universitas Negeri Surabaya Press, 2001).

${ }^{13}$ A. Khozin Afandi, Berpikir Teoritis Merancang Proposal (Surabaya: Pascasarjana IAIN Sunan Ampel Surabaya, 2006).

${ }^{14}$ Pratisto, Efektivitas Sikap Tanggap Guru Untuk Mengatasi Perilaku Destruktif Siswa Dalam Pembelajaran (Jakarta, 2013).

${ }^{15}$ Damanik, Dasma Alfriani. "Kekerasan Dalam Pendidikan: Tinjauan Sosiologi Pendidikan Violence In The World of Education (A Sociology of Education Review).” Jurnal Sosiologi Nusantara 5, no. 1 (2019): 77-90. 
mental science, actions that disturb the peace and interests of others are seen as manifestations of mental disorders. It is a result of mental pressures that cannot be adequately expressed. Or in other words, "delinquency" is an expression of tension, anxiety, and anxiety or mental stress (frustration). ${ }^{16}$

Sometimes the crime that a person commits is not because he or she lacks materiality but is a manifestation of dissatisfaction, disappointment, or depression, feeling less attention. Apart from expressing a restless heart, it is also possible for his actions to seek attention or retribution for unpleasant actions and treatment. ${ }^{17}$

Several factors cause destructive behavior. For example, they lack inculcation of religious values in the family, lack of parental understanding of education, irregular time filling, instability of social, political, and economic conditions, moral and mental decline of adults, many films and books well-read. ${ }^{18}$

\section{Social Action and Community Social Structure}

In this case, Weber classifies social actions that occur in learning into four parts that can affect society's social system and structure, including students in Madura. Among others are; first instrumental rationality. Here the social action that a person carries out is based on considerations and conscious choices related to the purpose of the action and the tools used to achieve it. ${ }^{19}$

The second, value-oriented rationality. The rational nature of this type of action is that the means that exist are only conscious deliberation and calculation, while the aims are already concerning the absolute values of the individual.

Third, traditional action. In this type of action, a person displays certain behaviors due to habits that have been devised from the ancestors, without conscious reflection or planning. Fourth, affective action. Feelings or emotions dominate this type of action without the intellectual consideration of mindful planning.

Thus, what Weber said, in line with the theory of exchange developed by George Homan, ${ }^{20}$ can be broadly returned to the following three propositions: First, If behavior or events that have passed in the context of specific stimuli and

${ }^{16}$ Khaerul Umam Noer, "Mencegah Tindak Kekerasan Pada Anak Di Lembaga Pendidikan," SAWWA: Jurnal Studi Gender 14, no. 1 (2019): 47-66.

${ }^{17}$ Nur Cholifa Maulut Di y ah and Ali Imron, "Kekerasan Dalam Pendidikan (Studi Fenomenologi Perilaku Kekerasan Di Panti Rehabilitasi Sosial Anak),” Paradigma 4, no. 3 (2016): 1-12.

${ }^{18}$ Etty Padmiati, "Melindungi Anak Dari Kekerasan ProtectingChildren from Violence," Media Informasi Penelitian Kesejahteraan Sosial 39, no. 1 (2015): 31-42.

${ }^{19}$ Hari Santoso, Kebijakan Perpustakaan Dalam Menghadapi Perilaku Destruktif Pemakai Pada Perpustakaan Perguruan Tinggi (Malang: Universitas Negeri Malang, 2008).

${ }^{20}$ Noer, "Mencegah Tindak Kekerasan Pada Anak Di Lembaga Pendidikan." 
situations are rewarded, likely, behavior or events that have a relationship between the same encouragement and condition will occur or be carried out. It means the phenomenon of this destructive behavior will occur continuously without stopping and constantly. Suppose there is the neglect of certain parties who have the obligation, authority, and authority to discipline and direct this student or a small group of people into a more meaningful, dignified activity and educating by prioritizing interactions that are ethical, moral, and have values. Suppose the government, community leaders, parents, or teachers ignore it. In that case, the destructive behavior of these students will occur continuously without stopping and without end. It will continue to develop in other phenomena in schools and madrasah. ${ }^{21}$

\section{FINDINGS AND DISCUSSION}

\section{Students' Verbal Destructive Behavior to Teacher in the Teaching-Learning Process}

According to Rogers in Pratisto that destructive is an interfering behavior or behavior in the teaching-learning process. They often act impolitely, irresponsible, and often break the rules. Those behaviors often make the teacher angry, annoyed, and cannot teach well..$^{22}$

There are kinds of students' behavior that can be categorized into destructive behavior. For instance, calling the teacher all the time, talking out of context, talking by themselves in the classroom while the teacher is explaining, showing exaggerated motoric anxiety (hyperactive, annoying, walking in the classroom all the time, and swinging on the chair), having an over-loud voice at the classroom, often doing something out of the assignment given, paying no attention and even having no concentration on the subject..$^{23}$

Those behaviors often happen in the classroom. If they cannot be handled well, they can ruin the teaching and learning process so that the purpose of the teaching cannot be gained smoothly. A destructive attitude or behavior is an attitude that violates norms caused by many and various emotions on the students. Therefore, destructive behavior can be said as an early symptom of having revenge on the teacher or showing individual identity in the teaching and learning process. ${ }^{24}$

\footnotetext{
${ }^{21}$ Muhlis, "Urgency of Arabic Language to the Religious Style of Madurese Society."

${ }^{22}$ Muhlis, "Urgency of Arabic Language to the Religious Style of Madurese Society."

${ }^{23}$ Pratisto, Efektivitas Sikap Tanggap Guru Untuk Mengatasi Perilaku Destruktif Siswa Dalam Pembelajaran.

${ }^{24}$ Wenny Wijayanti and Agustinus Djokowidodo, "Menakar Dampak Kekerasan Verbal Dalam Pembelajaran Oleh Guru Terhadap Peserta Didik Di SMP Se-Kota Madiun," in Desiminasai Hasil Penelitian Dan Pengabdian Kepada Masyarakat Menuju Era Revolusi Industri 4.0 Dan New Society, n.d., 40-43.
} 
This destructive verbal behavior can be seen in the spoken or written destructive form to the teacher. This behavior shows that the students thought the teacher is an ordinary human with no use or even having a lower social level than them. Therefore, the students tend to underestimate and saying a rude words to them. The students did this behavior to the teacher to show their dislike to the teacher. ${ }^{25}$

This destructive behavior happens to Farid Rofiq, an Arabic teacher from one of State Islamic Junior High School in Madura. He often recorded his students' says and misbehave, which belongs to destructive, such as "korang ajer (God damn it)," "tak beres (insane)," "Pate'(dog)." Besides, many students show impolite behavior, disrespect to their teacher.

They underestimate the existence of the teacher. The students with destructive behavior are the students who come from low intellectual levels. However, still, they think they are the best and brightest among others. Many students speak with a high voice to their teacher, such as "huuuuuu," "tidak!", "du apah (unimportant)," "ma' labedeh beih be'en pak (you have your own business)," je' wat magawat (don't be so strict), " and others. ${ }^{26}$

Even more, the students strike the teacher's matter out of his/ her capacity as a teacher. Sometimes, they even make fun of the teacher's physical appearance. For instance, a teacher is not so high for about $140 \mathrm{~cm}$ in height; they call him "se penttet datang (the dwarf is coming)", they even challenge him a fight. ${ }^{27}$

The students' destructive behavior toward their teacher was often found by a teacher Ibu Syamsiyah, S.Pd., a Math teacher of MTsN 3 Pamekasan. They use spoken or written rude words. Such as “du de'emma'ah pak (It's impossible, sir?)", "je' be'en ta' bengal (You would never be brave, Sir)" and others. These expressions show that the teacher cannot teach. They do not have bravery in facing the students. ${ }^{28}$

This destructive behavior was also obviously done by the students in front of their teacher. It happened to Mr. Lutfi, S.Pd, a sports teacher of MTsN 3 Pamekasan. His student threatened him because he warned one of his students who broke the rule. The student said "awas," e kabele'ah ka eppa (keep alert, sir. I'll report you to my father)", "eambe'eh e lorong (I'll wait for you on the way home)," "majuh mon atokarah e loar (come outside to fight!)." and others. ${ }^{29}$

${ }^{25}$ Leni Dwi Nurmala, "Perlindungan Hukum Terhadap Tenaga Pendidik," Gorontalo Law Review 1, no. 1 (2018): 67-76.

${ }^{26}$ Farid Rofiq, "Interview" (Pamekasan, 2019).

${ }^{27}$ Fawaid Arifin, "Interview" (Pamekasan, 2019).

${ }^{28}$ Mohammad Fadil, "Interview" (Pamekasan, 2019).

29 Syamsiyah, "Interview” (Pamekasan, 2019). 
In the process of teaching and learning in the classroom, Mr. Ali Hisyam, S.Sos.I, a counselor teacher of MTsN 3 Pamekasan teacher, heard a student stated, "I'm lazy to go to school, Sir." Spontaneously, Mr. Ali said, "if you are lazy to be at school, it's better for you to go home earlier." The joke by Mr. Ali was taken into granted by the student, and he went home directly. It was so because the student is so naughty and often late to come to school, so he was so brave to take the risk, and he went home directly. ${ }^{30}$

Another was happening experienced by Mrs. Robiatul Adawiyah, teacher of MTsN 1 Sampang, a counselor teacher in MTsN in Madura. She stated that to solve the students' destructive behavior. She sent their parent letters to school and doing home visits to meet the parents, but these efforts are in vain because they work outside the town. On another occasion, she asked for the parents' information by asking them, "Where did your parent go? Why did they not come to school for the invitation? And why did not we meet anyone at your house?" Spontaneously, they are shouting and hit the table in front of their teacher. ${ }^{31}$

The above description shows that the form of students' verbal destructive behavior toward their teacher is in a spoken or written way. It happens because the students' background knowledge does not understand and do the essence of ethics and akhlaq. The potency of destructive behavior in State Islamic Junior High School (MTsN) in Madura is still at a high level of happening. It needs all education stakeholders to think about this problem. ${ }^{32}$

There is some students' verbal destructive behavior to teachers. They are as follows.

"korang ajer (God damn it)"

"tak beres (insane)"

"Pate' (dog)"

"du apah (unimportant)"

"ma' labedeh beih be'en pak (you have your own business)"

"Je' wat magawat (don't be so strict)."

"du de'emma'ah pak (It's impossible, sir?)."

"je' be'en ta' bengal (You would never be brave, Sir)."

"awas," e kabele'ah ka eppa (keep alert, sir. I'll report you to my father)",

"eambe'eh e lorong (I'll wait for you on the way home)."

"majuh mon atorakah e loar (come outside to fight!)."

"sengkah engko' se asakola'ah pak" (lazy to go to school)

"agigir/menggertak" (bully / scold)

\section{Students' Physical Destructive Behavior toward Teacher in Teaching-Learning Process}

Destructive behavior done by students to their teacher was done in the form of spoken and written ways to harm the teacher psychologically but physically to

\footnotetext{
${ }^{30}$ Uswatun Hasanah, "Interview” (Pamekasan, 2019).

${ }^{31}$ Ali Hisyam, "Interview" (Pamekasan, 2019).

32 Robiatul Adawiyah, "Interview” (Pamekasan, 2019).
} 
harm the teachers' physical safety. So it seems that teachers with the knowledge and "title" on their name do not have enought qualifications for teaching. They need to have self-defense skill to overcome the students' destructive behavior, which sometimes is also supported by the parents. ${ }^{33}$

The teacher's role is to teach and transfer knowledge to their students. But the fact sometimes contrary, we found that there is a fight because the students are angry at what the teacher did to them. However, it is for the students' sake. They do not realize that it is for their sake later in life. So they fight with destructive behavior, which harms their teacher's physical aspect. ${ }^{34}$

As an exemplary case, a teacher in MTsN in Madura got physical harassment of being beaten and slapped over by the student. One day, a student was given punishment because he broke the rule in the school. After that, the student and his parents directly came to school and beat the teacher without confirming the student's behavior to the school. The beating and slapping are revenge for the teacher's punishment to the student at school. ${ }^{35}$

First, it happened to Mr. Mabrur and Mr. Chatib, and this also happened to Mr. Lutfi, teacher of MTsN 3 Pamekasan. He was also physically mistreated because of giving his students punishment for breaking the rule. The student decided to go home and told his parent about the sentence he got, and directly the parents went to school to beat the teacher.

Secondly, it happened to Mrs. Uswatun Hasanah, S.Pd, an English teacher of MTsN 3 Pamekasan in Madura. The story was so pitiful and dramatic. One of her students was following her on the way home from school. She thought positively that the student would do nothing at first. The student reproached her by imitating the way she walks. Mrs. Uswatun got information from other students that the naughty student was following her behind. Therefore, Mrs. Uswatun gave him punishment. The case is continuing. Further, the parents of the naughty student came to school, met, and reproved her as if she was not their child's teacher. As a woman, Mrs. Uswatun just tried to be patient and silent. ${ }^{36}$

Besides physical harassment, teachers of MTsN in Madura also experienced behavior that shows the students' dislike to the teacher. As it happened to Mr. Ali Hisyam, S.Sos.I, a counselor teacher of MTsN 3 Pamekasan. "They often refused me to shake hands; maybe they still feel angry at the punishment I gave them as the counselor teacher," he said. He is responsible for giving guidance, warning

${ }^{33}$ Wijayanti and Djokowidodo, "Menakar Dampak Kekerasan Verbal Dalam Pembelajaran Oleh Guru Terhadap Peserta Didik Di SMP Se-Kota Madiun."

${ }^{34}$ Nahuda et al., Pencegahan Kekerasan Terhadap Anak Di Lingkungan Pendidikan (Pusat Pelayanan Terpadu Pemberdayaan Perempuan Dan Anak (P2TP2A) Provinsi DKI Jakarta, 2007).

${ }^{35}$ Noer, "Mencegah Tindak Kekerasan Pada Anak Di Lembaga Pendidikan.”

${ }^{36}$ Luthfi, "Interview" (Pamekasan, 2019). 
students who break the rule at school, and breaking the norms and ethics agreed and applied in Madrasah. Mr. Ali Hisyam tried to be patient, although some students did not want to shake hands with him. He was not offended and always tried to give guidance to make the students have a better attitude. Thus, they can be helpful for religion and nation. ${ }^{37}$

The students' lousy attitude toward their teacher to show their dislike also happened to Mr. Mohammad Holis, an Arabic teacher of MTsN in Madura. Some students liked to make noise in the classroom, chat with their friends, make jokes noisily, do not do the assignment, etc. Here, Mr. Holis gave them punishment to stand in front of their friends until the end of the class. As a result, when he met the students outside the course, they turned their faces away and did not want to face him directly. However, these destructive behaviors did not lessen Mr. Holis' spirit of teaching and developing the Arabic subject's teaching quality. He believes that later in life, they will realize that this destructive behavior is also bad for themselves and others. Therefore, he keeps trying to make the students better both academically and mentally. ${ }^{38}$

\section{Students' Mental Destructive Behavior toward the Teacher in Teaching- Learning Process}

The third destructive form is mental destructive. Not all students have high motivation in the process of teaching and learning. A low motivated student seems to have destructive behavior toward his/ her teacher during the teachinglearning process. The teachers' purpose is only to make the students the material well. In this case, the students' mental destructive behavior leads to bad behavior to their teacher, such as first, the students like to grumble for something they did not like. ${ }^{39}$ It happened in Mr. Abd. Haq's class, he is an Arabic teacher of MTsN in Madura. He found his student grumbled at a task he assigned for them. They think it was too much. Mr. Abd. Haq had already offered the task for the student first, but no one responding or rejecting. When the assignment is given to them, most of the students grumbled; maybe at first, they were afraid to abandon the task. He often said, "come on, who thinks this task is too hard" every time he gave a task, but the students remained silent. In another word, they only grumbled after the teacher. ${ }^{40}$

Secondly, the students show sour faces. It also happened to Mr. Abd. Haq. The problem was similar; it was about the assignment which the students think

\footnotetext{
${ }^{37}$ Hasanah, "Interview."

${ }^{38}$ Hisyam, "Interview."

${ }^{39}$ Mohammad Holis, "Interview" (Pamekasan, 2019).

${ }^{40}$ Damanik, "Kekerasan Dalam Dunia Pendidikan: Tinjauan Sosiologi Pendidikan Violence In The World of Education (A Sociology of Education Review)."
} 
too hard for them. They were disappointed because the task given was not proper with their want. The Arabic teacher felt that this problem was the usual thing and did not need to be questioned anymore. ${ }^{41}$

Third, there is a student who does not want to come if the teacher is calling. At first, the teacher thought that it was because the student was a shame. After some investigation, it was known that he did it because he felt guilty and felt that he broke the rule. It happened many times. While to get the advantage and barakah of the knowledge, we need to be obedient to teachers. ${ }^{42}$

Fourth, the students felt traumatic feelings after getting the punishment. Mohammad Saleh, one of the teachers in MTsN in Madura, found traumatic students after getting punishment from the teacher. One day, when Mohammad Saleh taught his class, he saw a student was daydreaming. He asked the student whether he understood the material or not; the student kept silent and even seemed afraid. After asking the rest of the students in that class, they explained that the student was traumatic for not understanding the material presented in the previous meeting. ${ }^{43}$

Fifth, the students like to laugh at the teaching-learning process. Laughing in the classroom is a usual thing for students when they see, feel something funny. But something becomes odd if there is a student is laughing when there is nothing funny. It has happened in Abu Bakar's class. Suddenly, some students laughed at the classroom, whereas there is no other funny object to be laughed at. He was confused because he felt he was being laughed at by his students in his classroom when teaching. ${ }^{44}$

Sixth, the students get used to telling their parents to ask for help/ defend when they have punishment from their teacher. There are two kinds of parents here. One is the parents realize and know that their child does fault and even thank the teacher's guide. Still, another type has. They gave the teacher reasons for their child's mistake; even some parents used rude words to teachers who gave punishment to their child. However, they know that the purpose of giving them a penalty is for the sake of the students themselves. ${ }^{45}$ All in all, there was some students' mental destructive behavior to the teachers. They were grumbling attitude, surly, avoiding to meet the teacher, traumatic perspective, laugh a lot, and report to parents.

${ }^{41}$ Damanik, "Kekerasan Dalam Dunia Pendidikan: Tinjauan Sosiologi Pendidikan Violence In The World of Education (A Sociology of Education Review)."

42 Abd Haq, "Interview" (Pamekasan, 2019).

${ }^{43}$ Mohammad Ilyas, "Interview" (Pamekasan, 2019).

${ }^{44}$ Mohammad Saleh, "Interview” (Pamekasan, 2019).

${ }^{45}$ Abu Bakar, "Interview” (Pamekasan, 2019). 


\section{Factors Affecting the Students' Destructive Behavior toward the Teacher in Teaching-Learning Process}

Various factors affect the students' bad behavior breaking the normsthat has been agreed and applied in the school for many years. Two factors are affecting the students' destructive behavior toward the teacher in the teaching-learning process. They are internal and external factors. ${ }^{46}$

Internal factors affecting the students' destructive behavior toward the teacher in teaching are that first, the students' social status is higher than their teacher. In Madura, the social group becomes the economic modality for showing power in social life. The family's economic story influences the level of social class in Madura. A prosperous family, respected family (such as family from the village's headman, kyai, dukun, or government officers), and the "Bajingan" level have the bravery to do so carok. There many students who have higher social status than their teacher in MTsN in Madura. It should be understood that economically, most teachers in Madura are weak, so it makes the students sometimes weaken their position. Therefore, it often happens in Madura. The students with higher family background levels or having more prosperous economic status tend to be arrogant in having relationships with the teacher. ${ }^{47}$

Based on Weber's theory, the social behavior in the teaching-learning context influencing the social structure system in society is categorized into instrumental rationality destructive behavior. Students do some resistance because they have enough social modality. Even more than that, some students have full support to resist if they are given punishment from the teacher, although the sentence is for the students' sake. The economic, social status of the parents influenced the students' personality very much. It is to socialize, behave in society, the dressing style, the way to speak. They tend to underestimate teachers as if the teachers have nothing to be compared with because of their weak economic status. The students think that they can do everything with economic power. ${ }^{48}$

Secondly, the students think that they have higher knowledge and intelligence than their teacher. When the students are more brilliant and cleverer than the teacher, they underestimate their teachers for being more intelligent. This kind of student does not realize that the teacher's competency mainly comes from the teacher's help. The student even resisted by rejecting or arguing what the teacher said. ${ }^{49}$ It is because they are still young and want to take attention from

${ }^{46}$ M. Chatib, "Interview" (Pamekasan, 2019).

${ }^{47}$ Nita Ariyulinda, "Penanganan Kekerasan Terhadap Anak Melalui UU Tentang Sistem Pendidikan Nasional Dan UU Tentang Perlindungan Anak,” Journal Rechtsvinding; Media Pembinaan Hukum Nasional 1, no. 1 (2013): 1-5.

${ }^{48}$ Kairun Rasyad, "Interview” (Sumenep, 2019).

${ }^{49}$ Diyah and Imron, "Kekerasan Dalam Pendidikan ( Studi Fenomenologi Perilaku Kekerasan Di Panti Rehabilitasi Sosial Anak ).” 
people around them. They are trying to show themselves off their friends even by underestimating the teacher who has already given them knowledge. ${ }^{50}$ Based on Weber's theory, social behavior in a teaching-learning context can influence society's social structure and system. It would belong to value-based rationality destructive behavior. The students did destructive behavior for getting personal value which is absolute. They want to be categorized into the best, the smartest. Sometimes, they did not bring any stationery such as books, pencils, or erasers to school. However, they know that it was breaking the rule. ${ }^{51}$

Third, the students want to show their existence. In the second factor, the students did the destructive behavior because they have higher knowledge and intelligence than their teacher. In that case, it is contrary to the third factor. The students do not have enough knowledge to show their existence in front of their friends..$^{52}$ Based on Weber's theory, when we relate this social behavior with a teaching learning context that can influence society's social structure and its system, it is categorized into the students' affective destructive behavior that is only based on feeling or emotion without intellectual reflection or consciousness planning in behaving. This behavior can be in the form of laziness, disturbing other people, breaking the rules, not wearing shocks, having no haircut, using no tie, etc. It does not mean that they do not know that they will get punishment if they break the rule. Students cannot control their emotions, they like to have jokes, but they are easily angry or "temperament." They have unstable and unpredictable feelings, cannot maintain the sense, and tend to be contrary to the teacher. However, they know that they would get punishment. ${ }^{53}$

The fourth is the family's influence. The students of MTsN in Madura come from various family backgrounds, both their social, economic levels and parents' educational experience. Some students come from temperamental families, such as students from Sampang, Bangkalan, and Pamekasan regency. They realize that the consequence of violating the school regulation is adding the violating score. It can lead to failing a grade, but they still violate the rule; they are so brave of not obeying the teacher and the administration at school. ${ }^{54}$ Based on Weber's theory, when we relate this social behavior with the teaching learning context that can influence society's social structure and system belongs to the students' affective destructive behavior, which is based only on feeling or emotion without

50 Saleh, "Interview."

${ }^{51}$ Haq, "Interview."

${ }^{52}$ Tamsil Muis, Muhammad Syafiq, and Siti Ina Savira, "Bentuk, Penyebab, Dan Dampak Dari Tindak Kekerasan Guru Terhadap Siswa Dalam Interaksi Mengajar Dari Perspektif Siswa Di SMPN Kota Surabaya; Sebuah Survey," Jurnal Psikologi Teori \& Terapan 1, no. 2 (2011): 63-74.

${ }^{53}$ Fahruddin, "Interview" (Pamekasan, 2019).

${ }^{54}$ Hisyam, "Interview." 
intellectual reflection or conscious planning behaving toward a teacher. The students cannot control their feelings and like to joke but easily be angry or temperament. This kind of student has unstable and unpredictable emotions, cannot control the emotion, and tend to be contrary and against the teacher. ${ }^{55}$

The external factors affecting the students' destructive behavior toward their teacher in the teaching-learning process are, the first is the influence of information and technology development. It cannot be denied that the students have already united with information technology. Its existence influences the students' way of thinking and attitude very much. There are many negative attitudes that the students did come from the influence of information technology development. Nowadays, sophisticated information technology seems to be a knife with two sides. One side gives a positive impact because we can use it to get learning sources, including communication roles. Still, another side can negatively impact. It can be used to access an instant way of thinking and narrow the students' emotional quotient, which forms them to be an individualist. It is the reason why we urgently require characteristic building in madrasah to be developed continuously.

Hedonic culture is already spread. It is identical to the facility and luxurious goods owned by adults such as cars, motorcycles, blackberry, exaggerated use of Facebook, Twitter, and texting, is already spread. Madura, as like other big cities, cannot run from this development. Boyband/Girlband has become a new pandemic for the youngsters in Madura. Our society now is getting the boyband/ girlband fever. Many people suddenly become boyband/girlband because of this addiction. Motor gangs, being intoxicated, brawling among students, and many other examples are related to nowadays youngster's morality.

The second is the western way of life. Nowadays, the students' style and way of life are different from the old-time where the students live short and straightforward lives. Western-style is attacking students in Madura, including in the education part of MTsN. The effect is marvelous. There are students in madrasah who said and behaved unethically to their teacher because of television and social media. For example, YouTube, Whatsapp text, BMM, Instagram, telegram, etc, which spread all over Madura to attack the students' brain. ${ }^{56}$ Valentine's day which is identical to pink. Youngsters tend to spend time with their couples. It leads the youngsters to have free sex. They think they would be like ancient when they do not have a date. They are so proud of having many and diverse girlfriends/boyfriends at many times. If they think they are suitable for their couple, they break them out-the haircut and dressing in a sexy

${ }^{55}$ Rasyad, "Interview."

${ }^{56}$ Damanik, "Kekerasan Dalam Pendidikan: Tinjauan Sosiologi Pendidikan Violence In The World of Education (A Sociology of Education Review)." 
manner. Alay, abbreviated from "anak layangan" is the exaggerated youngster's life in fashion style, sayings, and behavior. These youngsters often wear strange dressing such as a light color dress with excessive accessories. Their behaviors are also exaggerating. They have an odd way of speaking, and it is different from other people in their society. They also made strange gestures while talking or doing something. ${ }^{57}$

The third is the effect of drugs and alcoholic drinks. Lately, Madura has become the destination for drug spread in "sabu- sabu" and alcoholic beverages. The spread is not only among teenagers and adults but also the students from junior high school. The more often the children consume drugs and alcoholic drinks, it would affect their thinking stability and the way to make a decision that leads to behavior. Behavior without a stable thinking process would create unstable behavior. In Madura, drug abuse becomes the crucial problem, social crime, which leads to physical harassment. It was the story behind the emergence of Kampung Narkoba in Bangkalan, a troubled zone for drugs in the northern coast of Sampang, to the building of Lapas Narkotika in Pamekasan and the spread of narcotics in Sumenep's archipelago. It supports the statement that drug abuse is worrying, showing that drug abuse is a social crime, and it belongs to the crime that cannot be tolerated and contrary to our ideology and norms because it can give a systemic effect on other crimes. Besides, the consumption of book material and film also allows students to express hidden feelings besides stimulating them to follow and imitate them in their daily activities. Finally, they imitate and exemplify heroes who do not have good morals in their reading material and films. ${ }^{58}$

The fourth is the overload learning burden. Sometimes, the students are forced to learn many things at a time. Teachers often give the students many homework and assignments without any correction, which makes the students disbelief the teacher and implies lousy behavior toward the teacher. Here the students may felt depressed, and they would do something odd. Moreover, it also happens when the teacher corrects the students' work without appreciating it. They should understand the students' work and treat them fairly. ${ }^{59}$

The fifth is that the teacher uses the rude word to students. It occasionally happens when the teacher is saying something rude to students. There is also the kind of teacher who likes to say something rude; whether they realize it or not, those harsh words would make a bad image of them in front of their students. It

${ }^{57}$ Chatib, "Interview."

${ }^{58}$ Moh Wardi, "Penerapan Nilai Pendidikan Agama Islam Dalam Perubahan Sosial Remaja,” TADRIS: Jurnal Pendidikan Islam 7, no. 1 Juni (2013).

${ }^{59}$ Santoso, Kebijakan Perpustakaan Dalam Menghadapi Perilaku Destruktif Pemakai Pada Perpustakaan Perguruan Tinggi. 
also triggers students to do destructive behavior to them. They would also reply to the teacher with rude words..$^{60}$ In other words, the students' violent behavior is because they are imitating what their teacher did. The teacher became the one in charge in the classroom so that it makes him do what he wishes, like running the show by himself, doing what he likes to do, and disregarding what the students want even when it is not sufficient time and place. It allows the students to take revenge. The teachers in this madrasah already protested it because it does not match Madurese's culture, which is friendly, polite, and stern. ${ }^{61}$

The sixth is exaggerated punishment. Some teachers punished their students as they are willing to (giving point which is not suitable with their violation). However, the teacher is also an ordinary human being who can make mistakes and sin. They think that students are doing complicated offenses while they are not. It means that a professional attitude is also needed to solve the problems that happen to students. ${ }^{62}$

The Problem Solving for the Students' Destructive Behavior toward the Teacher in the Teaching-Learning Process

As an Islamic institution, one of its roles is for building the students' characteristics. MTsn in Madura would never make the destructive behavior goes on. MTsN in Madura took solutive steps to end those destructive behaviors by giving punishment based on the existing rules. From various forms of destructive behaviors that happened in MTsN in Madura, as mentioned in the previous chapter, made the administrator of MTsN in Madura should create some efforts to repress the students' destructive behavior toward their teacher. The study recommended selecting both teaching materials and learning methods. Both were the opinions of Ibn Miskawayh and Naquib al- Attas and were further offered as a strategy to reduce the violence cases in Indonesia. ${ }^{63}$

The students may do the same destructive behavior with different effort because the personal conditions of students are also other. While the steps are giving guidance, exemplary and the parents' involvement in "home visit." The administrator of the madrasah applied various ways in solving the destructive behavior that happens in MTsN in Madura. One of them is giving guidance and training the students to do positive activities in the school's environment, especially spiritual development. ${ }^{64}$

${ }^{60}$ St Fatimah, "Interview" (Pamekasan, 2019).

${ }^{61}$ Hasanah, "Interview."

${ }^{62}$ Saleh, "Interview."

${ }^{63}$ Abdullah Aly and Muhammad Thoyibi, "Violence in Online Media And Its Implication To Islamic Education of Indonesia," IJIMS: Indonesian Journal of Islam and Muslim Societies 10, no. 1 (2020): 177-98, https://doi.org/10.18326/ijims.v10i1.177-198.

${ }^{64}$ Subairi, "Interview" (Pamekasan, 2019). 
Based on Weber's exchange theory which George Homan develops, ${ }^{65}$ stated that changing someone's personality can be done by making them involved in a habituation activity that is more meaningful, dignified, and educated. ${ }^{66}$ As a relevant implementation of this theory, first, the vice headmaster of the students' sector in one of MTsN in Madura made the agenda to wait for the students every morning at the school's front door. Second, the vice headmaster watched the students' coming every morning to know that they are discipline in time and dressing.

The students would feel that they are being watched and controlled by the teacher. So they are motivated to obey the rules at the school. For example, the obligation is to come five minutes before the class starts and dress in tidy, such as wearing socks, belt, shoes, and complete uniform as stated in the school's rule. Therefore, its purpose is to monitor and give the students good example not to come late to school and dress tidy as stated in the school's management. Besides that, the teachers and vice headmaster check the students' attributes such as shoes, shocks, and other features. Therefore, teachers must become change agents for promoting education for social justice. ${ }^{67}$

Every morning, MTsN in Madura hold Dhuha prayer together, recite AlQur'an, read Asma'ul Husna. ${ }^{68}$ These efforts are trying to engage the students into a better religious relationship with God. Therefore, it is hoped that the students' relations will form a better behavior based on religious teachings, including not harming others. Besides spiritual coaching, the headmaster also gives guidance programs in the classroom. It is done by specific personnel. For instance, counselors and religious teachers can significantly affect the students, moral modeling, moral knowing, moral feeling, and moral habituation. ${ }^{69}$

The couch in the classroom is taken from the respected teachers. So, the students feel disinclined and can receive what the teacher said. The material or the coaching content talks much about the essence of togetherness, harmony, and violence prevention. One of them is building good relations between teacher and students in an obedient, polite, and sincere manner. Those manners must be there in the teaching-learning process to gain benefits and barakah of

${ }^{65}$ Nahuda et al., Pencegahan Kekerasan Terhadap Anak Di Lingkungan Pendidikan.

${ }^{66}$ Ritzer, Sosiologi Ilmu Pengatahuan Berparadigma Ganda.

${ }^{67}$ Raihani, "A Model of Islamic Teacher Education For Social Justice In Indonesia A Critical Pedagogy Perspective," Journal of Indonesian Islam 14, no. 1 (2020): 163-86, https:// doi.org/10.15642/JIIS.2020.14.1.163-186.

${ }^{68}$ Muhlis, "Komunikasi Verbal Dalam Pengembangan Pembelajaran Bahasa Arab Berbasis Media Bithaqah Al-Jaibiyah."

${ }^{69}$ Chusnul Muali and Robiatul Aini, "Total Moral Quality Sebagai Konsep Pendidikan Karakter Di Pesantren; Sebuah Kajian Kritis Pemikiran Hasan Baharun,” Cendekia 17, no. 1 (2019): 133-58. 
knowledge. From this effort, it is hoped to minimize the destructive behavior. Thus it is necessary to disseminate and transform ethical doctrines in Islamic Education through Islamic Ethic. ${ }^{70}$

Destructive behavior in Madura can be done by using school and society's structural potency to minimize the strength of violent behavior. Structural aspects in an institution are all elements in the school (from the headmaster, teachers, and students) related to catastrophic problems. The headmaster and teachers are responsible for creating a good relationship between parents and society to establish a corporation to prevent and build a communication system so that it can identify the outside potency that can support destructive behavior. The administrators of MTsN in Madura do a personal approach to create emotional relations with the outsiders who have a significant role in the family. If a student does violence, the school will send a letter to parents to come to school, but if this effort is in vain, the institution will do the home visit program. ${ }^{71}$

The second way is giving educated punishment. Punishment is the consequence of doing destructive behavior done by the students to the teacher. By giving them punishment suitable with the existing mechanism, it is hoped to minimize the students' violent behavior toward their teacher. Moreover, punishment is the way to give the students lesson that destructive behavior is bad behavior and needs to be given a worthy punishment. Unfortunately, the problem that emerges nowadays is that the teacher should not do destructive behavior to the students because the students are under the protection of child protection laws. In contrast, the students are not allowed to do violent behavior. They are noble characters for doing noble duties, monitoring student behavior changes, and reporting on student character behavior and scoring.

MTs is an Islamic education institution with Islamic education principle views and teachings. In Islam's perspective, the relationship between teacher and students should be built based on obedience, politeness, sincere manner, and dedication. These are the fundamental values that need to be understood and implemented by the students and the parents so that there would be no destructive behavior that can fail the teaching-learning process. When violent behavior happens, one way to solve it is by giving the doer punishment to make them chary. As Mrs. Noor Indah stated, the students violated the school's regulations, like skipping the class, smoking at the school's area, and going home

${ }^{70}$ Zumrotul Mukaffa, "The Era of Uncertainty and Ethical Arragement in Javanese Classical Texts Disseminating Ranggawarsita' S Works as Source of Islamic Ethics in Islamic Higher Education," Al-J】mi 'ah: Journal of Islamic Studies 56, no. 2 (2018): 461-93, https://doi. org/10.14421/ajis.2018.562.461-493.

${ }^{71}$ Firman and Hidayat, "Strengthening Character Education Based On Golden Habits At SMP Muhammadiyah 1 Depok Yogyakarta.” 
earlier. The punishment given would be in the form of reciting Yasin, praying, and another thing in the yard of the school. ${ }^{72}$

The punishment must be given at every valance that happens, so it gives the students lesson, and they would not do it anymore. Every student is unique for having their characteristics and background. Some students are obedient, and they do not do violations anymore when they had already got punishment. On the contrary, some students got several penalties. Still, it does not stop him from doing a breach. For the latter students, the punishment should be continuously given to give him lesson not to violate any violation. In line with George Homan's stated that the more often punishment you got from other people, the less value of the following behavior would stay. In another word, we can hinder the development of destructive behavior by giving the doer punishment. ${ }^{73}$

The sufficient punishment for the above theory is by asking them to recite Surah Yasin in the schoolyard in front of the teachers and other students. Asking them to recite Al-Qur'an is not only giving an educated punishment, but it may also make them shy to do it again, for it is a moral value. When they are already shy, they will not try to repeat their destructive behavior. Thus, building the habituation of scientific matters in students' daily lives, namely: listening, paying attention, communication, cooperation, asking, doing, thinking, mutual respect, honesty, responsibility, and discipline. ${ }^{74}$

Dealing with destructive behavior, education institutions, including MTsN in Madura, have a clear and open mechanism so that outsiders relating to the problem will also identify it. We cannot handle destructive behavior partially; it must be comprehensive and integrated with other aspects. Counseling service must be fully supported by the institution leader (the headmaster) both in the form of the regulation product regarding the legal decision on the regulation and other moral support. This support and cooperation are the integral part that completes each other in solving the students' destructive behavior problems. The code or mechanism in giving the students punishment would be signed for the parents in supporting the school to make their children stop violating the school's rules.

The institution, including MTsN in Madura, can be seen from the students' behavior. It can be seen from the relationship between the student and teacher, the interaction between the students and the parent, interaction between the student and the social environment. It also involves the students and the teacher

${ }^{72}$ Noor Indah, "Interview” (Sampang, 2019).

${ }^{73}$ Muhlis, "Komunikasi Verbal Dalam Pengembangan Pembelajaran Bahasa Arab Berbasis Media Bithaqah Al-Jaibiyah."

${ }^{74}$ Budiyono Saputro et al., "Moral Reconstruction of Elementary Educational Level Student in Millenial Era: A Scientific Approach Perspective," Cendekia 17, no. 1 (2019): 159-69. 
interaction between the students and the natural environment. Therefore, if it is good, the educational institution can be categorized as successful in running the teaching-learning process.

Society's put their trust and interest in enrolling their children to the madrasah. "Madrasah lebih baik, lebih baik madrasah" jargon would never neglect the parents' satisfaction with the service quality MTsN, which gives services to their children. Education service quality plays a strategic role in the future. The service quality correlates significantly to the users' satisfaction. When the service quality meets the parents' expectations, they would be satisfied. On the other hand, when the service quality does not meet the parents' expectations, they would not be happy. ${ }^{75}$

Two main factors influence service quality: the expected service and the perceived service. Therefore, the service quality can be measured by comparing the expected benefit with the perceived service gained by the users. When the expected service meets the perceived one, the quality categorized as good and satisfying. On the other hand, if the perceived service goes beyond the expected benefit, the service quality is considered ideal. On the contrary, when the perceived service is lower than expected, the service quality is terrible or unsatisfying. Therefore the perfect and the lousy service quality depend on the capability of the administrator of MTsN in Madura to fulfill the parents' expectations.

\section{CONCLUSION}

Students' destructive behavior toward the teacher in the teaching-learning process in State Islamic Junior High School in Madura consists of violent verbal behavior, physical destructive behavior, and destructive mental behavior. The factors affecting the students' destructive attitude toward their teacher in the teaching-learning process of State Islamic Junior High School in Madura are the internal factor, in the form of the higher social status of the students than the teacher, the desire to show their existence, and the family's influence. In contrast, the external factor consists of technological information's influence, the students' lifestyle, drug abuse, alcoholic impact. Therefore, the students' destructive behavior toward their teacher in the teaching and learning process of State Islamic Junior High School in Madura gives them coaching/ guidance, exemplary, parents' involvement in "home visit" program, and educating their punishment.

${ }^{75}$ B.W Sutjipto, Strategi Manajemen Kualitas Dalam Era Globalisasi (Malang: Usahawan, 2013). 


\section{REFERENCES}

Adawiyah, Robiatul. "Interview." Pamekasan, 2019.

Afandi, A. Khozin. Berpikir Teoritis Merancang Proposal. Surabaya: Pascasarjana IAIN Sunan Ampel Surabaya, 2006.

Aly, Abdullah, and Muhammad Thoyibi. "Violence in Online Media And Its Implication To Islamic Education of Indonesia." IJIMS: Indonesian Journal of Islam and Muslim Societies 10, no. 1 (2020): 177-98. https://doi. org/10.18326/ijims.v10i1.177-198.

Arifin, Fawaid. “Interview.” Pamekasan, 2019.

Ariyulinda, Nita. "Penanganan Kekerasan Terhadap Anak Melalui UU Tentang Sistem Pendidikan Nasional Dan UU Tentang Perlindungan Anak.” Journal Rechtsvinding; Media Pembinaan Hukum Nasional 1, no. 1 (2013): 1-5.

Aziz, Abd. "Zawawi-Kasus-Budi-Tragedi-Kemanusiaan-Paling-Tragis-Video." Antara Jatim, April 26, 2018.

Bakar, Abu. "Interview." Pamekasan, 2019.

Basrowi, and Sukidin. Metode Penelitian Kualitatif Perspektif Mikro. Surabaya: Insan Cendekia, 2002.

Chatib, M. “Interview.” Pamekasan, 2019.

Damanik, Dasma Alfriani. "Kekerasan Dalam Pendidikan: Tinjauan Sosiologi Pendidikan Violence In The World of Education (A Sociology of Education Review).” Jurnal Sosiologi Nusantara 5, no. 1 (2019): 77-90.

Diyah, Nur Cholifa Maulut, and Ali Imron. "Kekerasan Dalam Pendidikan (Studi Fenomenologi Perilaku Kekerasan Di Panti Rehabilitasi Sosial Anak)." Paradigma 4, no. 3 (2016): 1-12.

Fadil, Mohammad. "Interview." Pamekasan, 2019.

Fahruddin. "Interview." Pamekasan, 2019.

Fatimah, St. "Interview.” Pamekasan, 2019. 
Firman, Arham Junaidi, and Nur Hidayat. "Strengthening Character Education Based On Golden Habits At SMP Muhammadiyah 1 Depok Yogyakarta." Cendekia 18, no. 2 (2020): 189-210.

Hadziq, Abdulloh. "Pendidikan Antikekerasan Berwawasan Lingkungan." AtTarbawi 3, no. 1 (2018): 55-71.

Haq, Abd. "Interview." Pamekasan, 2019.

Hasanah, Uswatun. “Interview.” Pamekasan, 2019.

Hisyam, Ali. "Interview." Pamekasan, 2019.

Holis, Mohammad. "Interview." Pamekasan, 2019.

Ilyas, Mohammad. “Interview.” Pamekasan, 2019.

Indah, Noor. "Interview." Sampang, 2019.

Jatmiko, Datu. "Peran Stakeholder Sekolah Dalam Mengatasi Berbagai Macam Kekerasan Di Kalangan Siswa.” Efektor 4, no. April (2017): 7-13.

Luthfi. "Interview." Pamekasan, 2019.

Muali, Chusnul, and Robiatul Aini. "Total Moral Quality Sebagai Konsep Pendidikan Karakter Di Pesantren; Sebuah Kajian Kritis Pemikiran Hasan Baharun.” Cendekia 17, no. 1 (2019): 133-58.

Muhlis, Achmad. "Komunikasi Verbal Dalam Pengembangan Pembelajaran Bahasa Arab Berbasis Media Bithaqah Al-Jaibiyah." Jurnal Okara Bahasa Dan Sastra 2, no. November (2016).

_- "Urgency of Arabic Language to the Religious Style of Madurese Society." In 1st International Conference on Islamic Studies Islam A Friendly Cultural Religion. Pamekasan, 2017.

Muis, Tamsil. "Tindakan Kekerasan Guru Terhadap Siswa Dalam Interaksi Belajar Mengajar (Studi Kasus Di SMAN Surabaya).” Jurnal Pendidikan 2, no. 1 (2017): 72-76.

Muis, Tamsil, Muhammad Syafiq, and Siti Ina Savira. "Bentuk, Penyebab, Dan Dampak Dari Tindak Kekerasan Guru Terhadap Siswa Dalam Interaksi Mengajar Dari Perspektif Siswa Di SMPN Kota Surabaya; Sebuah Survey.” Jurnal Psikologi Teori \& Terapan 1, no. 2 (2011): 63-74. 
Mukaffa, Zumrotul. "The Era of Uncertainty and Ethical Arragement in Javanese Classical Texts Disseminating Ranggawarsita 'S Works as Source of Islamic Ethics in Islamic Higher Education.” Al-Jlmi'ah: Journal of Islamic Studies 56, no. 2 (2018): 461-93. https://doi.org/10.14421/ajis.2018.562.461-493.

Nahuda, Gino Purnomo, Niniek Agus Widjojo, Febiana, Suswandari, Evita Adnan, Kanthi Lestari, M. Rezfah Omar, Haryati, and Yayah Edi Tarmidi. Pencegahan Kekerasan Terhadap Anak Di Lingkungan Pendidikan. PUSAT PELAYANAN TERPADU PEMBERDAYAAN PEREMPUAN DAN ANAK (P2TP2A) PROVINSI DKI JAKARTA, 2007.

Noer, Khaerul Umam. "Mencegah Tindak Kekerasan Pada Anak Di Lembaga Pendidikan." SAWWA: Jurnal Studi Gender 14, no. 1 (2019): 47-66.

Padmiati, Etty. "Melindungi Anak Dari Kekerasan ProtectingChildren from Violence." Media Informasi Penelitian Kesejahteraan Sosial 39, no. 1 (2015): 31-42.

Pratisto. Efektivitas Sikap Tanggap Guru Untuk Mengatasi Perilaku Destruktif Siswa Dalam Pembelajaran. Jakarta, 2013.

Prayitno, Elida. Psikologi Perkembangan Remaja. Padang: Angkasa Raya, 2006.

Raihani. "A Model of Islamic Teacher Education For Social Justice In Indonesia A Critical Pedagogy Perspective." Journal of Indonesian Islam 14, no. 1 (2020): 163-86. https://doi.org/10.15642/JIIS.2020.14.1.163-186.

Rasyad, Kairun. "Interview." Sumenep, 2019.

Ritzer, George. Sosiologi Ilmu Pengatahuan Berparadigma Ganda. Jakarta: PT. Raja Granginfo Persada, 2014.

Rofiq, Farid. "Interview." Pamekasan, 2019.

Saleh, Mohammad. "Interview.” Pamekasan, 2019.

Santoso, Hari. Kebijakan Perpustakaan Dalam Menghadapi Perilaku Destruktif Pemakai Pada Perpustakaan Perguruan Tinggi. Malang: Universitas Negeri Malang, 2008.

Saputro, Budiyono, Anis Khoerani, Laylatul Faizah, and Bikrotul Azizah. "Moral Reconstruction of Elementary Educational Level Student in Millenial Era: A Scientific Approach Perspective." Cendekia 17, no. 1 (2019): 159-69.

Subairi. "Interview." Pamekasan, 2019. 
Sudikan, Seya Yuwana. Metode Penelitian Kebudayaan. Surabaya: Universitas Negeri Surabaya Press, 2001.

Sutjipto, B.W. Strategi Manajemen Kualitas Dalam Era Globalisasi. Malang: Usahawan, 2013.

Syamsiyah. "Interview." Pamekasan, 2019.

Wardi, Moh. "Penerapan Nilai Pendidikan Agama Islam Dalam Perubahan Sosial Remaja.” TADRIS: Jurnal Pendidikan Islam 7, no. 1 Juni (2013).

Weber, Max. Etika Protestan Dan Spirit Kapitalisme. Edited by TW Utomo and Yusup Priya Sudiarja. Yogyakarta: Pustaka Pelajar, 2006.

Wijayanti, Wenny, and Agustinus Djokowidodo. "Menakar Dampak Kekerasan Verbal Dalam Pembelajaran Oleh Guru Terhadap Peserta Didik Di SMP Se-Kota Madiun.” In Desiminasai Hasil Penelitian Dan Pengabdian Kepada Masyarakat Menuju Era Revolusi Industri 4.0 Dan New Society, 40-43, n.d. 